\title{
Suppression of Bacterial Blight on Mustard Greens with Host Plant Resistance and Acibenzolar-S-Methyl
}

Anthony P. Keinath, Clemson University, Coastal Research and Education Center; and W. Patrick Wechter and Mark W. Farnham, United States Department of Agriculture-Agricultural Research Service, U. S. Vegetable Laboratory, Charleston, SC 29414-5329

\begin{abstract}
Keinath, A. P., Wechter, W. P., and Farnham, M. W. 2016. Suppression of bacterial blight on mustard greens with host plant resistance and acibenzolar$S$-methyl. Plant Dis. 100:1921-1926.

Bacterial blight, caused by Pseudomonas cannabina pv. alisalensis, attacks the leaves of most brassica vegetables, including mustard greens (Brassica juncea). 'Carolina Broadleaf,' a new mustard cultivar, is resistant to bacterial blight, whereas 'Florida Broadleaf,' a commonly grown cultivar, is susceptible. Acibenzolar- $S$-methyl (trade name Actigard) has been used to manage bacterial diseases caused by $P$. syringae on a variety of crops. The objective of this study was to evaluate host plant resistance and acibenzolar- $S$-methyl alone and in combination to manage bacterial blight. Three field experiments were done in spring and fall 2011 and fall 2014. In each experiment, acibenzolar-S-methyl was applied twice as a foliar spray, once before and once after plants were inoculated. Severity of bacterial

blight was $81 \%$ less on nontreated Carolina Broadleaf than on nontreated Florida Broadleaf $(P \leq 0.0003)$. Acibenzolar- $S$-methyl applications reduced severity of bacterial blight by $55 \%$ compared with the water control treatment on susceptible Florida Broadleaf. Mean weight of diseased leaves, averaged across acibenzolar- $S$-methyl treatments, was $53 \%$ less with Carolina Broadleaf than with Florida Broadleaf $(P<0.0001)$. However, acibenzolar- $S$-methyl applied at the recommended rate $(14.2 \mathrm{~g} / \mathrm{ha})$ significantly injured leaves of Carolina Broadleaf in two experiments and injured leaves of Florida Broadleaf in one experiment. Overall, host plant resistance was more effective than acibenzolar-S-methyl for managing bacterial blight on mustard greens.
\end{abstract}

Pseudomonas cannabina pv. alisalensis is the causal agent of bacterial blight on leafy brassica greens, a group of related crops that includes collard and kale (both Brassica oleracea L.), mustard greens (B. juncea L.), and turnip greens and broccoli rabe (both B. rapa L.) (Bull et al. 2010; Koike et al. 1998; Wechter et al. 2013). Bacterial blight has been present in South Carolina since at least 2001 (Keinath et al. 2006b). Marketable yields of leafy brassicas are reduced by up to $24 \%$, because bacterial blight degrades the edible portion of these crops (Smith and Keinath 2004; Wechter et al. 2013). Previous crop losses in South Carolina have been as much as $\$ 1.7$ million in a single year (Smith and Keinath 2004). Although P. cannabina pv. alisalensis attacks many brassica vegetables, disease symptoms are more severe and economic losses are greater on mustard and turnip greens than on kale, broccoli, collard, or cabbage (Koike et al. 1998, 2006, 2007; Smith and Keinath 2004; Wechter et al. 2010, 2013, 2014). Currently, approximately 850 ha of mustard greens and 1,200 ha of turnip greens are produced annually in South Carolina. Broadleaf mustard, primarily 'Florida Broadleaf', accounts for $35 \%$ of the mustard produced, and the remaining $65 \%$ is curly leaf cultivars such as 'Southern Giant Curled.' Of the total hectares, 200 and 285 ha of mustard and turnip greens, respectively, or $24 \%$, are for processing (J. P. Smith, personal communications).

Plant Introduction G 30988, a broadleaf mustard green, has a high level of resistance to $P$. cannabina pv. alisalensis (Wechter et al. 2007). When inoculated with $P$. cannabina pv. alisalensis in the field, it had $<0.60 \%$ mean leaf area diseased and a significantly greater weight of healthy leaves than mustard greens Southern Giant Curled and Florida Broadleaf. 'Carolina Broadleaf' is a resistant selection $\left(\mathrm{S}_{3}\right)$ of $\mathrm{G} 30988$. Evidence indicates that the resistance to $P$. cannabina pv. alisalensis

\section{Corresponding author: A. P. Keinath; E-mail: tknth@ clemson.edu}

This material is based upon work supported, in part, by the National Institute of Food and Agriculture-United States Department of Agriculture under project number SC-1700446. Technical Contribution number 6410, Clemson University Experiment Station.

Accepted for publication 5 May 2016.

http://dx.doi.org/10.1094/PDIS-02-16-0202-RE

(C) 2016 The American Phytopathological Society exhibited by Carolina Broadleaf is controlled by more than one recessive gene (Wechter et al. 2013). Seed of Carolina Broadleaf is extremely limited, given the comparatively small market for mustard greens seed, relative to other vegetable brassica crops such as cabbage and broccoli. Thus, until sufficient seed of Carolina Broadleaf is available, additional measures are needed to manage this disease.

Acibenzolar-S-methyl (ASM; Actigard 50WG and Bion 50WG; Syngenta Crop Protection, Greensboro, NC), a benzothiadiazole, induces the salicylic acid pathway in plants after application (Görlach et al. 1996). It has been tested and used as a supplement, alternative, or replacement for conventional bactericides such as fixed coppers (Louws et al. 2001; Vallad and Goodman 2004; Walters et al. 2013). Severity of bacterial speck and in planta growth of $P$. syringae pv. tomato was significantly lower in plants inoculated 5 days after treatment with ASM than in nontreated plants (Scarponi et al. 2001). The authors concluded that the protection was due to induced resistance, because the concentration of ASM in tomato leaves had decreased to the limit of detection $72 \mathrm{~h}$ after application. ASM also reduced bacterial speck on tomato in various locations in the eastern United States (Louws et al. 2001). In addition to $P$. syringae pv. tomato, ASM has been successfully tested or applied to manage diseases caused by other pathovars of $P$. syringae such as $P$. syringae pv. actinidiae on kiwifruit, $P$. syringae pv. garcae on coffee seedlings, and $P$. syringae pv. syringae on tomato and mango (Cazorla et al. 2006; Gilardi et al. 2010; Monchiero et al. 2015; Patrício et al. 2008). In a resistant wild bean accession, ASM enhanced resistance to bacterial blight caused by $P$. syringae pv. syringae (Córdova-Campos et al. 2012). Thus, ASM appears to be a good candidate to manage P. cannabina pv. alisalensis on susceptible and resistant mustard greens. Currently, ASM is registered in the United States to manage downy mildew and black rot, caused by Xanthomonas campestris pv. campestris, on brassica vegetables. The combination of host plant resistance in Carolina Broadleaf and ASM might allow growers to harvest a normal amount of leaves from fields in which $P$. cannabina pv. alisalensis is present.

In addition to $P$. cannabina pv. alisalensis, distinct leaf-spotting strains of $X$. campestris pv. campestris also have been found on leafy brassicas in South Carolina (Wechter et al. 2008). In two on-farm experiments, ASM reduced the severity of leaf spot or the area under the disease progress curve on turnip greens infected with both $P$. cannabina 
pv. alisalensis and X. campestris pv. campestris (Keinath et al. 2007a,b). Effects of ASM on yields of turnip greens were variable in these experiments. In the summer experiment, in which $X$. campestris pv. campestris was the predominant pathogen, ASM did not increase the percentage of healthy leaves or the fresh weight of turnip greens (Keinath et al. 2007a). In the spring experiment, in which both pathogens were isolated from diseased leaves harvested, ASM increased fresh weight of turnip leaves by $63 \%$ and the percentage of healthy leaves by over $100 \%$ (Keinath et al. 2007b). Because both pathogens were present, it was not possible to determine whether the control observed resulted from suppression of $P$. cannabina pv. alisalensis, $X$. campestris pv. campestris, or both pathogens.

To be able to investigate control of $P$. cannabina pv. alisalensis by ASM without interference from $X$. campestris pv. campestris, additional experiments were done in Charleston, $\mathrm{SC}$, where neither pathogen is present naturally. The objectives of this study were to (i) evaluate host plant resistance, ASM, and the combination for management of bacterial blight on mustard greens; and (ii) determine the effects of a resistant genotype and ASM on yield of mustard greens.

\section{Materials and Methods}

Three field experiments were done in April to May 2011, September to November 2011, and September to October 2014 at the Clemson University Coastal Research and Education Center in Charleston, SC. The fields used had a $\mathrm{pH}$ of 6.2, 6.1, and 5.9, respectively. The preceding crops in the fields were crimson clover (Trifolium incarnatum) in winter 2010-11, various cucurbits in spring 2011, and winter rye (Secale cereale) and fallow in spring 2014, respectively. Fields were disked twice and $10 \mathrm{~N}-10 \mathrm{P}-10 \mathrm{~K}$ fertilizer at 448 to $560 \mathrm{~kg} / \mathrm{ha}$ was applied based on soil nutrient analysis. In fall 2011 and 2014, plants were side dressed with $15.5 \mathrm{~N}-0 \mathrm{P}-0 \mathrm{~K}$ calcium nitrate at $336 \mathrm{~kg} / \mathrm{ha}$ and $34 \mathrm{~N}-0 \mathrm{P}-0 \mathrm{~K}$ ammonium nitrate at $280 \mathrm{~kg} / \mathrm{ha}$, respectively, approximately 5 weeks after transplanting. The preemergent herbicide napropamid (Devrinol 50WP) was applied at $2.2 \mathrm{~kg} / \mathrm{ha}$ after raised beds were formed. In spring 2011, pyraclostrobin (Cabrio 20EG) was applied once to manage Cercospora leaf spot; in fall 2011, pyraclostrobin and cyprodinil-fludioxonil (Switch 62.5WG) were each applied twice in rotation to prevent Cercospora leaf spot; and in fall 2014, pyraclostrobin was applied three times and cyprodinil-difenoconazole (Inspire Super 2.82SC) was applied once to prevent Cercospora leaf spot and Alternaria leaf spot.

In spring 2011, the experimental design was a split plot, with Florida Broadleaf (susceptible) or Carolina Broadleaf (resistant) as the whole plot and ASM as the subplot, with six replications. In fall 2011 and 2014, a randomized complete-block experimental design was used with six replications. Plots were arranged on 0.9-m-wide raised beds spaced $0.9 \mathrm{~m}$ apart, with one nonplanted bed between each planted bed. Mustard greens were seeded in the greenhouse on 15 March 2011, 26 August 2011, and 14 August 2014. On 12 April 2011, 21 September 2011, and 10 September 2014, 40 plants were transplanted into each plot in two rows; plants were spaced $15 \mathrm{~cm}$ apart within rows and the rows were $30 \mathrm{~cm}$ apart. Plots were $3.0 \mathrm{~m}$ long and separated by $0.3 \mathrm{~m}$ of nonplanted space within rows.

ASM (14.2 g/ha) was applied in a volume of 46 liters/ha on 28 April and 5 May 2011, 12 and 19 October 2011, and 30 September and 8 October 2014 with a $\mathrm{CO}_{2}$-backpack sprayer operated at 414 newton $/ \mathrm{m}^{2}$ with a $0.9-\mathrm{m}$ boom and two TeeJet 8002 VS nozzles (Spraying Systems Co., Wheaton, IL) spaced $0.45 \mathrm{~m}$ apart. Control plots were sprayed with water. All plants were inoculated with P. cannabina pv. alisalensis isolate TC3 on 29 April 2011, 14 October 2011, and 3 October 2014, as described by Wechter et al. (2013), except that the inoculum suspension was adjusted to an optical density at $600 \mathrm{~nm}$ of 0.2 (approximately $10^{7} \mathrm{CFU} / \mathrm{ml}$ ). To help establish the pathogen, leaf wetness was maintained by using low-pressure miniwobbler sprinklers (Senninger Irrigation, Clearwater, FL) to produce a mist for 30 to $60 \mathrm{~min}$ each evening from the day of inoculation until the last disease rating. On 4 and 13 May 2011, 31 October 2011, and 9 and 20 October 2014, plots were rated visually for percent leaf surface area with symptoms of bacterial blight and phytotoxicity using a 0 -to- $100 \%$ scale in $2.5 \%$ increments (Wechter et al. 2013). When plants were rated twice, the second rating is presented in the Results section.

On 13 May 2011, 1 November 2011, and 21 October 2014, all leaves within a $0.5-\mathrm{m}$ section of one row per plot were cut 2 to $3 \mathrm{~cm}$ above the soil line and separated into three classes based on percentage of the leaf surface area affected with bacterial blight. The fresh weight of the leaves in each class was measured. The three classes were symptomless $(0 \%)$, slightly diseased $(>0$ and $\leq 1 \%)$, and diseased $(>1 \%)$. A threshold of $1 \%$ severity was selected after discussions with commercial growers in South Carolina. Phytotoxicity was ignored when leaves were separated into disease classes.

Fresh leaf weights were further categorized into four yield components to analyze the effects of bacterial blight on yield. Total weight was the sum of the weights of all three classes. Marketable weight was defined as the sum of the weights of symptomless leaves plus leaves with disease severity $\leq 1 \%$. Percent marketable weight was calculated as the ratio of marketable leaves to total weight. Weight of all diseased leaves was the sum of the weights of both classes of diseased leaves.

Statistical analysis. Data on disease severity, phytotoxicity, fresh leaf weight, and yield components were analyzed with a mixed-model maximum-likelihood analysis using the PROC MIXED procedure of SAS (version 9.3; SAS, Inc., Cary, NC). Data from each experiment were analyzed separately and then combined, with the effect of experiment and its interaction included as fixed effects. Error variances for disease ratings were homogeneous among the three experiments based on Bartlett's test. Data were checked for nonnormality with PROC UNIVARIATE and, based on this test, percentage ratings for disease severity and phytotoxicity were transformed before analysis by calculating the arcsine of the square root. Fresh weights were transformed before analysis by calculating the base-ten logarithm. Residuals from analyses of variance were checked for nonnormality and inequality of variance with PROC UNIVARIATE. Least-squares treatment means were compared with Fisher's protected least significant difference. The SLICE option was used to examine significant interactions among treatments. Back-transformed leastsquares means are shown in the tables. Main effect means are presented in the Results section for datasets in which interactions among factors were not significant $(P>0.10)$.

\section{Results}

Disease ratings. The severity of bacterial blight varied among the three experiments ( $F$ for experiment was significant at $P=0.01$ ) but there was no interaction of experiment with cultivar or ASM treatment $(P \geq 0.18)$ (Table 1$)$. Mean severity calculated across all treatments was significantly greater in fall 2011 than in spring $2011(P=$ $0.004)$, whereas severity in fall 2014 was intermediate and did not differ from severities in the other two experiments. Rainfall totaled 5.77, 3.23, and $1.65 \mathrm{~cm}$ and fell on 7, 3, and 2 days in fall 2011, fall 2014, and spring 2011, respectively. ASM applications significantly $(P<0.0001)$ reduced bacterial blight on susceptible Florida Broadleaf but not $(P=0.06)$ on resistant Carolina Broadleaf when compared with the water control, resulting in a significant $(P \leq 0.03)$ cultivar-ASM interaction, except in fall 2014 (Table 1). Bacterial blight was significantly $(P \leq 0$. 01) lower on resistant Carolina Broadleaf than on susceptible Florida Broadleaf regardless of ASM application in fall 2011 and for the mean across experiments. In spring 2011 and fall 2014, disease severity on Florida Broadleaf treated with ASM did not differ from disease severity on Carolina Broadleaf treated with water (Table 1).

In both experiments in 2011 but not in 2014, applications of ASM resulted in a significantly higher level of phytotoxicity on resistant Carolina Broadleaf than on susceptible Florida Broadleaf (Table 1). Symptoms consisted of yellowing of leaf laminae and twisting of entire leaves. In spring 2011, there was a significant cultivar-ASM interaction $(P=0.04)$, because ASM applications injured Carolina Broadleaf $(P=0.001)$ compared with its water control treatment but there were no symptoms of phytotoxicity on Florida Broadleaf. In fall 2011, symptoms of phytotoxicity on ASM-treated Carolina Broadleaf were more severe than the symptoms of bacterial blight on either cultivar 
(Table 1). In this experiment, phytotoxicity also occurred on Florida Broadleaf treated with ASM. There, again, was a significant cultivar-ASM interaction $(P=0.02)$, because phytotoxicity was greater on Carolina Broadleaf than on Florida Broadleaf treated with ASM $(P=0.001)$. In 2014, phytotoxicity was minimal and not significantly different among cultivars or ASM treatments (Table 1).

Yields. Fresh weights of symptomless leaves and slightly diseased leaves (i.e., leaves with disease severity $>0$ and $\leq 1 \%$ ) were affected by experiment and cultivar but not by ASM applications $(P \geq 0.08$; Table 2). Both cultivars produced more leaves that were symptomless in fall 2011 than in the other two experiments $(P<0.01)$. Fresh weights of symptomless leaves did not differ between the two cultivars in the two experiments done in 2011 but, in 2014, fresh weight of symptomless leaves of Carolina Broadleaf was almost twice that of Florida Broadleaf ( $P=0.0001$; Table 2). Weight of slightly diseased leaves was significantly less for Carolina Broadleaf than for Florida Broadleaf in $2014(P=0.0002)$ but weight of slightly diseased leaves did not differ by cultivar in the other two experiments (Table 2). Carolina Broadleaf had more slightly diseased leaves in fall 2011 than in the other two experiments $(P<0.01)$. Weight of slightly diseased leaves did not differ among years for Florida Broadleaf. In spring and fall 2011, fresh weight of diseased leaves with severity $>1 \%$ was twice as high for Florida Broadleaf as for Carolina Broadleaf but the two cultivars did not differ in 2014 (Table 2).

There were no significant interactions $(P>0.13)$ among experiment, cultivar, or ASM for fresh weight of all leaves harvested, marketable leaves, all diseased leaves, or percent marketable leaves. Fresh weight of marketable leaves and fresh weight of all leaves harvested did not differ $(P \geq 0.16)$ between cultivars or ASM treatments but weights were greater in fall 2011 than in the other two experiments (Table 3).

Experiment, cultivar, and ASM applications all significantly affected the weight of diseased leaves and the percentage of leaves that were marketable (Table 3). Weight of all diseased leaves (i.e., with severity $>0 \%)$ was lower in fall 2014 than in fall $2011(P=0.001)$. Weight of diseased leaves was 36\% lower with ASM (main effect mean across cultivars) than with water, and 53\% lower with Carolina Broadleaf than with Florida Broadleaf (main effect mean across ASM treatments) (Table 3). The percentage of marketable leaves (leaves without symptoms plus leaves with disease severity $\leq 1 \%$ ) followed similar trends (Table 3). A greater percentage of leaves (14\% more) was marketable when plants were treated with ASM than with water $(P<0.0001)$. Similarly, Carolina Broadleaf produced a greater percentage of marketable leaves (19\% more) than Florida Broadleaf $(P<0.0001)$. The greatest proportion of marketable leaves were produced in fall 2014 compared with the other 2 years $(P \leq 0.01)$.

Mean disease severity ratings ( $n=12$ for main effect means of experiment, cultivar, and ASM treatment) were highly $(P=0.009)$ positively correlated with mean weight of diseased leaves with severity $>1 \%(r=0.715)$ and with mean weight of all diseased leaves $(r=$ 0.712) (Fig. 1). Mean disease severity ratings were negatively

Table 1. Severity of bacterial blight and phytotoxicity of acibenzolar-S-methyl (ASM) applications on susceptible (Florida Broadleaf) and resistant (Carolina Broadleaf) mustard greens in three field experiments in South Carolina ${ }^{v}$

\begin{tabular}{|c|c|c|c|c|c|c|c|c|}
\hline \multirow[b]{2}{*}{ Cultivar } & \multirow[b]{2}{*}{ ASM } & \multicolumn{4}{|c|}{ Disease severity (\%) } & \multicolumn{3}{|c|}{ Phytotoxicity (\%) } \\
\hline & & Mean $^{w}$ & Spring 2011 ${ }^{x}$ & Fall $2011^{y}$ & Fall $2014^{y}$ & Spring $2011^{y}$ & Fall $2011^{x}$ & Fall 2014 \\
\hline Florida Broadleaf & None & $8.7 \mathrm{a}$ & $5.7 \mathrm{a}$ & $12.4 \mathrm{a}$ & $8.6 \mathrm{a}$ & $0.0 \mathrm{c}$ & $0.4 \mathrm{c}$ & 0.03 \\
\hline Florida Broadleaf & $14.2 \mathrm{~g} / \mathrm{ha}$ & $4.0 \mathrm{~b}$ & $2.5 \mathrm{~b}$ & $5.2 \mathrm{~b}$ & $4.4 \mathrm{~b}$ & $0.0 \mathrm{c}$ & $4.7 \mathrm{~b}$ & 0.7 \\
\hline Carolina Broadleaf & None & $1.7 \mathrm{c}$ & $1.2 \mathrm{bc}$ & $2.0 \mathrm{c}$ & $1.9 \mathrm{bc}$ & $1.8 \mathrm{~b}$ & $0.6 \mathrm{c}$ & 0.3 \\
\hline Carolina Broadleaf & $14.2 \mathrm{~g} / \mathrm{ha}$ & $1.1 \mathrm{c}$ & $1.0 \mathrm{c}$ & $1.7 \mathrm{c}$ & $0.7 \mathrm{c}$ & $4.3 \mathrm{a}$ & $21.7 \mathrm{a}$ & 0.8 \\
\hline \multicolumn{9}{|l|}{ Probability, source $\mathrm{z}$} \\
\hline Cultivar & $\ldots$ & $<0.0001$ & 0.0059 & 0.0053 & $<0.0001$ & 0.0003 & 0.0107 & 0.46 \\
\hline ASM & $\ldots$ & $<0.0001$ & 0.0103 & $<0.0001$ & 0.0022 & 0.0034 & $<0.0001$ & 0.07 \\
\hline Cultivar-ASM & $\ldots$ & 0.0005 & 0.0326 & 0.0152 & 0.4377 & 0.0360 & 0.0162 & 0.62 \\
\hline
\end{tabular}

${ }^{v}$ Mean percent leaf surface area with symptoms. Means were back-transformed from arcsine-square root transformation of percentage ratings used in the analysis of variance.

${ }^{w}$ Mean across experiments. Means within the same column with the same letter are not significantly different, Fisher's protected least significant difference (LSD) test, $P \leq 0.001$.

x Means within the same column with the same letter are not significantly different, Fisher's protected LSD test, $P \leq 0.05$.

y Means within the same column with the same letter are not significantly different, Fisher's protected LSD test, $P \leq 0.01$.

z Probability of a greater $F$ statistic for each source of variation.

Table 2. Yields of leaves by disease severity class harvested from susceptible (Florida Broadleaf) and resistant (Carolina Broadleaf) mustard greens affected with bacterial blight in three field experiments ${ }^{\mathrm{x}}$

\begin{tabular}{|c|c|c|c|c|}
\hline \multirow[b]{2}{*}{ Experiment } & \multirow[b]{2}{*}{ Cultivar } & \multicolumn{3}{|c|}{ Fresh weight $(\mathrm{kg} / 0.5 \mathrm{~m})^{\mathrm{y}}$} \\
\hline & & Symptomless & Slightly diseased (Sev $\leq 1 \%$ ) & Diseased $(\operatorname{Sev}>1 \%)$ \\
\hline Spring 2011 & Florida Broadleaf & $0.30 \mathrm{~cd}$ & $0.08 \mathrm{ab}$ & $0.27 \mathrm{ab}$ \\
\hline Spring 2011 & Carolina Broadleaf & $0.31 \mathrm{~cd}$ & $0.06 \mathrm{bc}$ & $0.14 \mathrm{~cd}$ \\
\hline Fall 2011 & Florida Broadleaf & $0.49 \mathrm{ab}$ & $0.14 \mathrm{ab}$ & $0.38 \mathrm{a}$ \\
\hline Fall 2011 & Carolina Broadleaf & $0.62 \mathrm{a}$ & $0.15 \mathrm{a}$ & $0.18 \mathrm{bc}$ \\
\hline Fall 2014 & Florida Broadleaf & $0.22 \mathrm{~d}$ & $0.13 \mathrm{ab}$ & $0.12 \mathrm{~cd}$ \\
\hline Fall 2014 & Carolina Broadleaf & $0.41 \mathrm{bc}$ & $0.03 \mathrm{c}$ & $0.08 \mathrm{~d}$ \\
\hline \multicolumn{5}{|l|}{ Probability, source ${ }^{z}$} \\
\hline Experiment & $\ldots$ & $<0.0001$ & 0.0200 & 0.0005 \\
\hline Cultivar & $\ldots$ & 0.0014 & 0.0040 & 0.0003 \\
\hline Experiment-cultivar & $\ldots$ & 0.0242 & 0.0054 & 0.6045 \\
\hline ASM & $\ldots$ & 0.0806 & 0.53 & 0.0049 \\
\hline
\end{tabular}

${ }^{x}$ All leaves in one $0.5-\mathrm{m}$ section of one row were cut at the bases of the plants and sorted into severity (Sev) categories. Means were back-transformed from baseten-logarithm-transformed values used in the analysis of variance.

${ }^{y}$ Means were calculated across acibenzolar-S-methyl (ASM) and water treatments, because these two treatments did not differ in any experiment $(P \geq 0.08)$. Means within the same column with the same letter are not significantly different, Fisher's protected least significant difference test, $P \leq 0.01$.

${ }^{\mathrm{z}}$ Probability of a greater $F$ statistic for each source of variation. 
correlated $(P=0.02)$ with percentage of leaves by weight that were marketable $(r=-0.664)$.

\section{Discussion}

Applications of ASM reduced the mean severity of bacterial blight on the susceptible mustard green Florida Broadleaf by 55\%. This is an additional use of ASM to manage a new species of Pseudomonas. ASM was more effective against bacterial canker on kiwifruit, caused by $P$. syringae pv. actinidiae, because it reduced foliar disease severity by an average of $81 \%$ (Monchiero et al. 2015). However, the kiwifruit were treated nine times with ASM in the greenhouse, with two applications prior to inoculation, whereas mustard greens were treated twice, with one application prior to inoculation. Similarly, ASM reduced severity of syringae blight on greenhouse tomato by $86 \%$ when it was applied 1 day prior to inoculation with $P$. syringae pv. syringae (Gilardi et al. 2010). ASM reduced the incidence of bacterial apical necrosis on mango, also caused by $P$. syringae pv. syringae, by $54 \%$ in the field (Cazorla et al. 2006). Across five field experiments in the eastern United States, ASM reduced foliar severity of bacterial speck on tomato, caused by P. syringae pv. tomato, by an average of $47 \%$ (Louws et al. 2001). Percent control ranged from 23 to $77 \%$ of the nontreated plots. This level of control is similar to the level obtained on leaves of susceptible mustard greens. In contrast to the control observed with ASM against diseases caused by $P$. syringae, ASM applications were ineffective against $P$. savastanoi pv. savastano $i$ on olive (Quesada et al. 2010).

Results with ASM, mustard greens, and bacterial blight caused by $P$. cannabina pv. alisalensis, which formerly was considered a pathovar of $P$. syringae, differed between the resistant and susceptible cultivars. ASM had no effect on the resistant cultivar but it reduced bacterial blight on the susceptible cultivar. Walters et al. (2013) cite several studies in which genotypes of barley, tomato, and bean varied in their responses to resistance inducers. ASM applications reduced severity of bacterial blight caused by $P$. syringae pv. syringae on a resistant wild accession of bean (Phaseolus vulgaris) but not on improved modern cultivars (Córdova-Campos et al. 2012). On a highly resistant wild accession, ASM had no effect. Because few hosts have resistance to Pseudomonas syringae, further generalizations about the interaction of ASM and host resistance cannot be made.

Applications of ASM reduced the amount of diseased leaves (with severity $>1 \%$ ) produced by both mustard green cultivars by an average of $36 \%$. Consequently, ASM also increased the percentage of marketable leaves, from a mean of $67 \%$ in nontreated plots to $78 \%$ in treated plots, because these diseased leaves were not included in marketable weight. Similarly, because ASM did not affect the weights of symptomless leaves or slightly diseased leaves, it also did not affect the weight of marketable leaves, which was the sum of these two classes. Thus, the primary benefit of ASM was to suppress development and limit the severity of bacterial blight. Weights of leaves treated with ASM would have been lower if leaves with phytotoxicity symptoms had been excluded. These leaves were included because the focus of the study was on bacterial blight; if growers use ASM, it would be at a rate or on a crop without phytotoxicity. The benefit of ASM might have been greater if bacterial blight had been more severe in this study. On commercial farms, disease sometimes has been much more severe on Florida Broadleaf, with up to $90 \%$ of the leaf surface area blighted (Wechter et al. 2014).

Use of Carolina Broadleaf in place of Florida Broadleaf reduced the amount of diseased leaves by $53 \%$, because mean leaf disease ratings were $81 \%$ lower on Carolina Broadleaf than on Florida Broadleaf. Consequently, the weight of symptomless leaves was

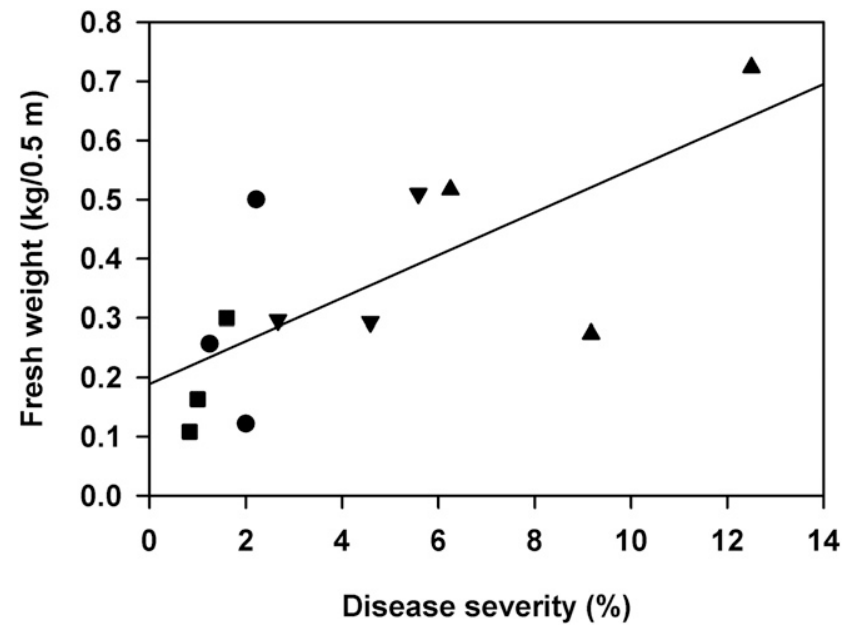

Fig. 1. Correlation of fresh weight of diseased leaves ( $y$-axis) with severity rating (percent leaf surface diseased). Pearson correlation coefficient $=0.712, P=0.0094$. Symbols: $\mathbf{\Delta}=$ Florida Broadleaf (susceptible) treated with water, $\mathbf{v}=$ Florida Broadleaf treated with acibenzolar-S-methyl, $\mathbf{0}=$ Carolina Broadleaf (resistant) treated with water, and $\boldsymbol{\bullet}=$ Carolina Broadleaf treated with acibenzolar-S-methyl.

Table 3. Yields of leaves classified by marketability harvested from susceptible (Florida Broadleaf) and resistant (Carolina Broadleaf) mustard greens affected with bacterial blight in three field experiments ${ }^{\mathrm{w}}$

\begin{tabular}{|c|c|c|c|c|c|c|}
\hline \multirow[b]{2}{*}{ Experiment } & \multirow[b]{2}{*}{ Cultivar } & \multirow[b]{2}{*}{ ASM } & \multicolumn{3}{|c|}{ Mean fresh weight of harvested leaves $(\mathrm{kg} / 0.5 \mathrm{~m})^{\mathrm{x}}$} & \multirow[b]{2}{*}{ Marketable (\%) } \\
\hline & & & All leaves & Marketable $(\operatorname{Sev} \leq 1 \%)^{y}$ & All diseased $(\mathrm{Sev}>0 \%)$ & \\
\hline Spring 2011 & $\ldots$ & $\ldots$ & $0.60 \mathrm{~b}$ & $0.38 \mathrm{~b}$ & $0.26 \mathrm{ab}$ & $64.9 \mathrm{~b}$ \\
\hline Fall 2011 & $\ldots$ & $\ldots$ & $1.03 \mathrm{a}$ & $0.73 \mathrm{a}$ & $0.40 \mathrm{a}$ & $72.2 \mathrm{~b}$ \\
\hline \multirow[t]{5}{*}{ Fall 2014} & $\ldots$ & $\ldots$ & $0.51 \mathrm{~b}$ & $0.41 \mathrm{~b}$ & $0.16 \mathrm{~b}$ & $80.8 \mathrm{a}$ \\
\hline & Florida Broadleaf & $\ldots$ & $0.64 \mathrm{NS}$ & $0.51 \mathrm{NS}$ & $0.37 *$ & $65.1 *$ \\
\hline & Carolina Broadleaf & $\ldots$ & 0.72 & 0.46 & 0.17 & 80.2 \\
\hline & $\ldots$ & None & $0.71 \mathrm{NS}$ & $0.46 \mathrm{NS}$ & $0.32 *$ & $67.1 *$ \\
\hline & $\ldots$ & $14.2 \mathrm{~g} / \mathrm{ha}$ & 0.65 & 0.50 & 0.20 & 78.1 \\
\hline \multicolumn{7}{|c|}{ Probability, source ${ }^{\mathrm{z}}$} \\
\hline Experiment & $\ldots$ & $\ldots$ & $<0.0001$ & $<0.0001$ & 0.0041 & 0.0003 \\
\hline Cultivar & $\ldots$ & $\ldots$ & 0.1565 & 0.1765 & $<0.0001$ & $<0.0001$ \\
\hline ASM & $\ldots$ & $\ldots$ & 0.2244 & 0.2381 & 0.002 & $<0.0001$ \\
\hline
\end{tabular}

${ }^{\mathrm{w}}$ All leaves in one 0.5 -m section of one row were cut at the bases of the plants and sorted into severity categories. Means were back-transformed from base-tenlogarithm-transformed values used in the analysis of variance.

${ }^{x}$ Means within the same column with the same letter are not significantly different, Fisher's protected least significant difference test, $P \leq 0.01$. An asterisk $(*)$ indicates that mean differs from the mean immediately below based on $F$ statistic at the probability indicated in the analysis of variance table; NS $=$ not significant.

y Marketable leaves are symptomless leaves plus leaves with severity $(\mathrm{Sev}) \leq 1 \%$ given in Table 2. Percent marketable is the ratio of marketable leaves to all leaves harvested.

${ }^{\mathrm{z}}$ Probability of a greater $F$ statistic for each source of variation. ASM = acibenzolar-S-methyl. Means shown are main effect means calculated across all levels of the other two factors, because no interaction terms were significant, $P \geq 0.13$. 
26 and $46 \%$ greater with Carolina Broadleaf than with Florida Broadleaf in fall 2011 and 2014, respectively. This led to a $23 \%$ increase, from 65 to $80 \%$, in the percentage of marketable weight with Carolina Broadleaf. Because weight of symptomless leaves did not differ between the two cultivars in the spring experiment, yields with Carolina Broadleaf in the presence of $P$. cannabina pv. alisalensis may be greater in the fall.

Both the susceptible and the resistant cultivars produced similar biomass (total fresh weight) in all three experiments. Thus, in the absence of bacterial blight, the resistant broadleaf cultivar is expected to yield as much as the current standard susceptible broadleaf cultivar. Although bacterial blight was severe on individual plants and leaves in this study, it was not severe enough to kill leaves or plants, possibly because plants reached marketable size between 14 and 18 days after inoculation.

In this study, disease severity ratings at harvest were correlated with weight of diseased leaves. In a previous study, the square roots of disease severity ratings were negatively correlated with weight of symptomless leaves (Wechter et al. 2013). Ratings and weight data were collected in the same way in both studies; therefore, it is unknown why disease severity correlated with different weight measurements in the two studies. Disease severity was greater in the experiments reported by Wechter et al. (2013) than in the current experiments, likely because a higher inoculum concentration was used to inoculate plants. Nevertheless, both studies demonstrate that visual ratings are a meaningful way to assess control measures for bacterial blight.

Vallad and Goodman (2004) and Walters et al. (2013) discuss the reduction in plant growth or yield occasionally associated with ASM applications. Total weight of mustard leaves harvested was $8.2 \%$ lower for plants sprayed with ASM (7.1 t/ha) compared with plants sprayed with water $(7.7 \mathrm{t} / \mathrm{ha}$ ) but the difference was not statistically significant $(P=0.22)$. Likewise, ASM reduced tomato yields by $11 \%$ compared with standard treatments but the difference between the two treatments was significant in only 1 of 11 field experiments (Louws et al. 2001). In Italy, ASM reduced the height and fresh weight of greenhouse-grown tomato plants in one of four trials (Gilardi et al. 2010).

Phytotoxicity precludes the use of ASM on Carolina Broadleaf and may limit the use on Florida Broadleaf. In previous trials in South Carolina, ASM did not produce any symptoms of phytotoxicity on turnip greens and rape salad greens (B. napus var. napus) (Keinath et al. 2006a, 2007a,b). Similarly, phytotoxicity was observed on mustard greens treated with copper hydroxide but not on turnip greens (Keinath et al. 2007a,b, 2015). Thus, ASM could be used on some leafy brassica greens other than mustard greens to manage bacterial blight. Louws et al. (2001) mentioned "little to no acute phytotoxicity in field tomatoes" treated with ASM but did not report ratings. Nine applications of ASM distorted the leaves of 1-year-old kiwi plants in three of four greenhouse experiments but not in two field experiments (Monchiero et al. 2015). The description of the symptoms on kiwi was similar to the twisting and distortion observed on Carolina Broadleaf mustard with two applications at comparable rates. Because ASM was effective against syringae blight on tomato and bacterial apical necrosis on mango at one-third to one-fifth the rate used on mustard, it might be possible to reduce the rate of ASM to reduce the likelihood and extent of phytotoxicity (Cazorla et al. 2006; Gilardi et al. 2010).

One application of ASM costs approximately $\$ 80 /$ ha, so the two applications used in this study would add $\$ 160 /$ ha to the production cost for mustard greens. Only two applications of ASM were made in this study, based on what growers consider acceptable input costs. However, the percentage of marketable leaves produced with the ASM treatment (78\%) was still below the desired level of $90 \%$ marketable leaves necessary to minimize the time associated with removing diseased leaves from the harvested product. Although four applications of ASM are allowed per crop, the additional cost and the additional risk of phytotoxicity preclude this number of applications to mustard greens.

In summary, although ASM reduced disease severity and the weight of diseased leaves, host plant resistance in Carolina Broadleaf was more effective than two applications of ASM. Weight of symptomless leaves was higher with Carolina Broadleaf than with Florida Broadleaf. Despite a tendency to bolt when temperatures exceed $29^{\circ} \mathrm{C}$, two large South Carolina growers who produce mustard greens for the fresh and processing markets have enthusiastically grown Carolina Broadleaf. When Carolina Broadleaf is grown in the fall season, premature bolting is not observed.

\section{Acknowledgments}

We thank M. L. MacMillan, V. B. DuBose, and D. Couillard for technical assistance.

\section{Literature Cited}

Bull, C. T., Manceau, C., Lydon, J., Kong, H. N., Vinatzer, B. A., and FisherLesaux, M. 2010. Pseudomonas cannabina pv. cannabina pv. nov., and Pseudomonas cannabina pv. alisalensis (Cintas Koike and Bull, 2000) comb. nov., are members of the emended species Pseudomonas cannabina (ex Sutic \& Dowson 1959) Gardan, Shafik, Belouin, Brosch, Grimont \& Grimont 1999. Syst. Appl. Microbiol. 33:105-115.

Cazorla, F. M., Arrebola, E., Olea, F., Velasco, L., Hermoso, J. M., Pérez-García, A., Torés, J. A., Farré, J. M., and de Vicente, A. 2006. Field evaluation of treatments for the control of the bacterial apical necrosis of mango (Mangifera indica) caused by Pseudomonas syringae pv. syringae. Eur. J. Plant Pathol. 116:279-288.

Córdova-Campos, O., Adame-Álvarez, R. M., Acosta-Gallegos, J. A., and Heil, M. 2012. Domestication affected the basal and induced disease resistance in common bean (Phaseolus vulgaris). Eur. J. Plant Pathol. 134:367-379.

Gilardi, G., Gullino, M. L., and Garibaldi, A. 2010. Evaluation of spray programmes for the management of leaf spot incited by Pseudomonas syringae pv. syringae on tomato cv. Cuore di bue. Crop Prot. 29:330-335

Görlach, J., Volrath, S., Knauf-Beiter, G., Hengy, G., Beckhove, U., Kogel, K.-H., Oostendorp, M., Staub, T., Ward, E., Kessmann, H., and Ryals, J. 1996 Benzothiadiazole, a nove1 class of inducers of systemic acquired resistance, activates gene expression and disease resistance in wheat. Plant Cell 8:629-643.

Keinath, A. P., DuBose, V. B., May, W. H., III, and Wechter, W. P. 2006a. Effect of Actigard on Xanthomonas leaf spot on rape greens, 2005. Online publication. Fungic. Nematicide Tests 61:V058.

Keinath, A. P., DuBose, V. B., May, W. H., III, and Wechter, W. P. 2007a Evaluation of Actigard and Kocide to manage bacterial leaf spots on turnip greens, 2006. Online publication. Plant Dis. Manage. Rep. 1:V103.

Keinath, A. P., DuBose, V. B., May, W. H., III, and Wechter, W. P. 2007b. Evaluation of biopesticides to manage bacterial leaf spots on turnip greens, 2006. Online publication. Plant Dis. Manage. Rep. 1:V104.

Keinath, A. P., DuBose, V. B., Wechter, W. P., and McMillan, M. 2015. Evaluation of Kocide and Actigard to manage bacterial blight on susceptible and resistan mustard greens, 2011. Online publication. Plant Dis. Manage. Rep. 9:V073.

Keinath, A. P., Wechter, W. P., and Smith, J. P. 2006b. First report of bacterial leaf spot on leafy Brassica greens caused by Pseudomonas syringae pv. maculicola in South Carolina. Plant Dis. 90:683.

Koike, S. T., Henderson, D. H., Azad, H. R., and Cooksey, D. A. 1998. Bacterial blight of broccoli raab: A new disease caused by a pathovar of Pseudomonas syringae. Plant Dis. 82:727-731.

Koike, S. T., Kammeijer, K., Bull, C. T., and O'Brien, R. D. 2006. First report of bacterial blight of romanesco cauliflower (Brassica oleracea var. botrytis) caused by Pseudomonas syringae pv. alisalensis in California. Plant Dis. 90:1551.

Koike, S. T., Kammeijer, K., Bull, C. T., and O'Brien, R. D. 2007. First report of bacterial blight of rutabaga (Brassica napus var. napobrassica) caused by Pseudomonas syringae pv. alisalensis in California. Plant Dis. 91:112.

Louws, F. J., Wilson, M., Campbell, H. L., Cuppels, D. A., Jones, J. B., Shoemaker, P. B., Sahin, F., and Miller, S. A. 2001. Field control of bacterial spot and bacterial speck of tomato using a plant activator. Plant Dis. 85:481-488.

Monchiero, M., Gullino, M. L., Pugliese, M., Spadaro, D., and Garibaldi, A. 2015 Efficacy of different chemical and biological products in the control of Pseudomonas syringae pv. actinidiae on kiwifruit. Australas. Plant Pathol. 44:13-23

Patrício, F. R. A., Almeida, I. M. G., Barros, B. C., Santos, A. S., and Frare, P. M. 2008. Effectiveness of acibenzolar- $S$-methyl, fungicides and antibiotics for the control of brown eye spot, bacterial blight, brown leaf spot and coffee rust in coffee. Ann. Appl. Biol. 152:29-39.

Quesada, J. M., Penyalver, R., Pérez-Panadés, J., Salcedo, C. I., Carbonell, E. A., María, M., and López, M. M. 2010. Comparison of chemical treatments for reducing epiphytic Pseudomonas savastanoi pv. savastanoi populations and for improving subsequent control of olive knot disease. Crop Prot. 29:1413-1420.

Scarponi, L., Buonaurio, R., and Martinetti, L. 2001. Persistence and translocation of a benzothiadiazole derivative in tomato plants in relation to systemic acquired resistance against Pseudomonas syringae pv. tomato. Pest Manage. Sci. 57:262-268.

Smith, J. P., and Keinath, A. P. 2004. Crop Profile for Leafy Greens and Collards (Fresh Market) in South Carolina. Online publication. USDA NIFA, Regional IPM Centers Information Network. 
Vallad, G. E., and Goodman, R. M. 2004. Systemic acquired resistance and induced systemic resistance in conventional agriculture. Crop Sci. 44: 1920-1934.

Walters, D. R., Ratsep, J., and Havis, N. D. 2013. Controlling crop diseases using induced resistance: Challenges for the future. J. Exp. Bot. 64:1263-1280.

Wechter, W. P., Farnham, M. W., Smith, J. P., and Keinath, A. P. 2007. Identification of resistance to peppery leaf spot among Brassica juncea and Brassica rapa plant introductions. HortScience 42:1140-1143.

Wechter, W. P., Keinath, A. P., Farnham, M. W., and Smith, J. P. 2010. First report of bacterial leaf blight on broccoli and cabbage caused by Pseudomonas syringae pv. alisalensis in South Carolina. Plant Dis. 94:132.
Wechter, W. P., Keinath, A. P., McMillan, M., Smith, J. P., and Farnham, M. W. 2013. Expression of bacterial blight resistance in Brassica leafy greens under field conditions and inheritance of resistance in a Brassica juncea source. Plant Dis. 97:131-137.

Wechter, W. P., Keinath, A. P., Smith, J. P., and Farnham, M. W. 2008. First report of severe outbreaks of bacterial leaf spot of leafy brassica greens caused by Xanthomonas campestris pv. campestris in South Carolina. Plant Dis. 92:1134. Wechter, W. P., Keinath, A. P., Smith, J. P., Farnham, M. W., Bull, C. T., and Schofield, D. A. 2014. First report of bacterial leaf blight on mustard greens (Brassica juncea) caused by Pseudomonas cannabina pv. alisalensis in Mississippi. Plant Dis. 98:1151. 